\title{
Turning To Animals Between Love And Law
}

\section{Anat Pick}

\begin{abstract}
As an alternative to Utilitarianism, animal ethics turned to the Continental philosophies of Levinas and Derrida that welcome and revere Otherness. While Utilitarianism relies on a 'closed' system of ethical calculations, the Levinasian model remains open-ended. This essay argues for a revised approach to animal ethics that combines Levinasian immeasurability, what Matthew Calarco called 'ethical agnosticism', with a closed approach that sees ethics as issuing from particular modes of practice. Highlighting some of the problems inherent in the Levinasian ethics of love as well as Agamben's biopolitical critique of law, I propose a corrective, 'between love and law', that avoids predetermining the limits of moral consideration yet insists on the social and normative dimensions of ethical responsiveness. I take the practice of veganism - broadly conceived beyond the strictly dietary - as the heart of animal ethics and consider some of the philosophical and theological dimensions of veganism as neither naïve nor as utopian but on the contrary, as a worldly mode of engagement that acknowledges the realities of violence.
\end{abstract}

Keywords transcendence and immanence, animal ethics, the problem of violence, veganism, Simone Weil, Gillian Rose, Donna Haraway

1. Simone Weil, Gravity and Grace (1947), Emma Crawford and Mario von der Ruhr (trans), London, Routledge, 2004, p4
Grace is the law of the descending movement. To lower oneself is to rise in the domain of moral gravity. Moral gravity makes us fall towards the heights.

\section{Simone Weil ${ }^{1}$}

Animal ethics is perhaps the clearest example of the demands of justice as the falling towards the heights. To consider animals we have to stop, and stoop, required to withhold most if not all of the descriptive and normative claims that furnish and shape our everyday. In recent developments, as an alternative to the dominant utilitarian and rights-based models, animal ethics turned to the Continental philosophies of Levinas and Derrida that welcome and revere Otherness. Whereas utilitarianism relies on a 'closed' system of ethical calculations, the Levinasian model remains open-ended. This essay argues for a revised approach to animal ethics that combines Levinasian immeasurability, the disposition Matthew Calarco describes as 'ethical agnosticism', with a closed approach that sees ethics as embodied in particular modes of practice. By highlighting some of the problems inherent in the Levinasian model of an ethics of love, I propose a corrective that avoids predetermining the limits of moral consideration yet insists on the social and normative dimensions of ethical responsiveness. I take the practice of veganism - broadly conceived 
beyond the strictly dietary - as the heart of animal ethics and consider some of the philosophical and theological dimensions of veganism as neither naïve nor as utopian but, on the contrary, as a worldly mode of engagement that acknowledges the realities of violence. Veganism's worldliness is an example of 'descending upwards' that gives shape to animal ethics, conjoining the openness of love with the delimited and bound system of law.

Preceding my discussion of veganism are a few reflections on contemporary Continental thought that has transformed animal ethics; the first two sections examine the dual theoretical track of transcendence and immanence that has been so important for developments in critical theory and posthumanist ethics. My critique of these two undercurrents informs the latter parts of the essay where I tackle the issue of animal ethics directly. My conclusion links veganism to abolitionist animal rights theory, which is rarely if ever considered from the perspective of Continental philosophy. If the route to the question of animal ethics seems tortuous, this is because my aim in this piece is to call attention to the theoretical temperament that underlies our thinking in the field. In other words, I am trying to connect ideas with the 'moods' that engender them, to better understand where and to what practical ends they might lead.

\section{ANIMALS AND THE SACRAL REALM OF EXCEPTION}

The work of ethics and of justice for Simone Weil is paradigmatically the movement of descending upwards- not figuratively but literally - and animals, routinely excluded from view and from the moral community, are a case in point. Animals' exclusion initially appears almost too self-evident to warrant comment, too visible to really appear. At all levels of life animals are subject to a catalogue of relentless bracketing. Morally, legally, politically, culturally, and religiously, animals are exemplars of exclusion, not merely symbolically, remaining outside or at the threshold of these various categories, but empirically: they embody a particular, and we might say an exclusive, case of exclusion. Despite what we know about the 'continuities of oppression' across species lines, nonhuman animals occupy an exceptional space, and the space of exception.

Yet as recent theorizing on animals and animality has shown, animals' very exceptionality endows them with a strange kind of agency which Matthew Calarco, following Derrida's 'The Animal That Therefore I Am (More to Follow)', describes as 'the disruptive force in animal suffering'. ${ }^{2}$ In their very exclusion, then, animals assert their proximity to and elicit a range of responses from us, from repression to violent retaliation to the recognition of animals' personhood. Eating animals, the most ubiquitous form of exclusion from the moral community, itself suggests the simultaneity of intimacy and distance since the practices of killing and ingesting, however mechanized and rationalized, may be said to bear the traces of the sacrificial economy

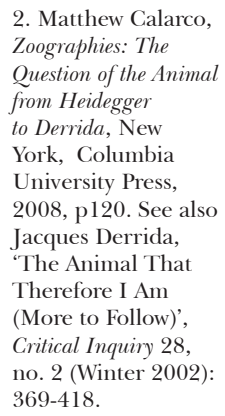


3. On meat eating and communion see my critique of Temple Grandin in Creaturely Poetics: Animality and Vulnerability in Literature and Film New York, Columbia University Press, 2011, pp68-69.

4. See Agamben's The Open: Man and Animal, Kevin Attell (trans), Stanford, Stanford University Press, 2002, and Levinas' 'The Name of a Dog, or Natural Rights', in Difficult Freedom: Essays on Judaism, Seán Hand (trans), London, Athlone Press, 1990, pp 151-3. See also 'The Paradox of Morality: an Interview with Emmanuel Levinas', in The Provocation of Levinas: Rethinking the Other, London, Routledge, 1988, Robert Bernasconi and David Wood (eds), pp168-80; and Calarco's 'Facing the Other Animal', in Zoographies, op. cit., pp55-77.

5. William E. Connolly, 'Pluralism and Faith,' in Political Theologies: Public Religions in a Post-Secular World, New York, Fordham University Press, 2006, Hent de Vries and Lawrence E. Sullivan, (eds), p284. See also Eugene Thacker, After Life, Chicago, University of Chicago Press, 2010, which 'isolates two traditions that address the ontology of life: the first is the dominant thread ... which constructs an ontology of life ... governed of communion. Indeed in most world religions, meat consumption remains subject to regulation and prohibition. ${ }^{3}$

Two seemingly opposing theories, whose central figure is the excluded, have informed recent formulations of animals' predicament: the first is the ethics of Emmanuel Levinas, the second the biopolitics of Giorgio Agamben. Levinas and Agamben have been at the heart of recent debates on ethics and politics but they have had an equally decisive impact on the way we conceive human-animal relations and the field of animal ethics. While Agamben and Levinas both touch on the question of animals, they do so reluctantly: in their accounts animality, not animals, is mobilized conceptually rather than concretely to explore the structure and function of otherness and othering in the configurations of subjectivity and politics. ${ }^{4}$

In what follows, I reflect on some of the ways in which the seemingly polar approaches of Levinas and Agamben have enlivened debates in animal ethics and yet also constrained our readiness to address the everyday consequences of animals' moral standing. I offer a brief description, or diagnosis, of the current tendency for a radicalized, or what I think of as the bipolar, theorization of exception in the context of moral attitudes towards animals. I then propose a mediating remedy to these tendencies, a remedy I name the 'creaturely'. This corrective is best understood in light of the recent emergence of post-secular theory that aims at a rapprochement between religion and the discourses of philosophy and politics. My aim is to show how theology comes to bear upon the 'question of the animal' and brings to light some of the difficulties inherent in the secular discourse that dominates animal ethics and separates divine from intellectual governance, and the bipolarity that pushes ethics towards the sacral exclusory realms of ethical or biopolitical messianism.

\section{THE BIPOLAR TURN: TRANSCENDENCE, IMMANENCE, AND THE PROBLEM OF VIOLENCE}

Discussing Leo Strauss' comments on Spinoza's excommunication, William E. Connolly argues that the 'persisting conflict' in the history of ideas 'is not exactly between "belief and unbelief", faith and reason, but, as it were, between different species of faith. Connolly describes this as 'the difference between a positive belief in transcendence over the world and a positive belief in the immanence of the world'. ${ }^{5}$ Not only have these orientations, towards transcendence and towards immanence, been crucial in shaping developments in critical theory, both have contributed a great deal to debates around the question of the animal and animal ethics.

The critical terrain between Levinas and Agamben has proved fertile in responding to dominant modes within the two, hardly mutually conversant, fields of political theory and animal studies. ${ }^{6}$ There is little doubt that biopolitics and poststructuralist ethics have disrupted our anthropocentric view of human and nonhuman life through their rigorous critiques of 
subjectivity. For Matthew Calarco, this critique is crucial to the development of a properly egalitarian 'universal moral consideration' that is 'fundamentally opposed to any and all perfectionism and...does not imply that certain beings should have lesser or inferior rights to those of human beings'. ${ }^{7}$ As Calarco explains:

The central issue concerning the critique of the metaphysics of subjectivity concerns more than the consequences of a certain legacy of Cartesian subjectivity in modernity and postmodernity; if this critique is understood in a rigorous manner, it leads us to see more fully the inner connection between metaphysical humanism and metaphysical anthropocentrism. ${ }^{8}$

In the name of a genuinely radical politics, neither humanistic nor anthropocentric, Calarco pursues the varieties of Continental postmetaphysical thought to their (logical) end, at which point they (logically) yield a postmetaphysical politics freed from the centripetal pull of humanism and anthropocentrism. I share Calarco's call for an ethics and politics whose ideas and objectives are not strictly human or anthropocentric as the only conceivable framework for opening to and accounting for the realities of all - human and other - lives. And yet the rapid rise of immanent biopolitics and transcendental ethics, both of which fall under the broad rubric of posthumanism, also reveals some interesting cultural impulses that I believe need to be identified and critiqued.

In his book The Problem With Grace, Vincent Lloyd examines the significance of the division between immanence and transcendence within the field of political theology (among those working within this field we can arguably count Agamben and Levinas, as well as theorists whose thought ranges across biopolitics and ethics, such as Judith Butler). Lloyd sees political theology as governed by a logic of worldly fallenness that seeks redemption in either immanent or in transcendent forms:

Political theology, as well as adjunct discourses such as theories of secularization, has focused on shifts between 'immanent' and 'transcendent' conceptions of God, noting how these correlate with different political structures. The requisite fix to the fallen world comes either from outside (in sovereign God or sovereign king) or from within. Such political theology reduced theology to the practice of pointing outside or pointing inside. Reducing the richness of theological tradition to two vague gestures leads directly into the trap of discarding Law in favor of Grace, for it focuses on modes of redemption rather than modes of living and acting, religiously or politically. ${ }^{9}$

Lloyd wants to move away from the either-or (inside-outside) approach, which reflects what he calls a 'supersessionist logic,' towards a 'middle path'. ${ }^{10}$ by transcendent emanation. The second tradition is a more radical, "heretical" orientation in which life is defined by negation, univocity-equivocity, and the concept of pantheistic immanence' (xii).

6. See Cary Wolfe's Before the Law: Humans and Other Animals in a Biopolitical Frame, Chicago, University of Chicago Press, forthcoming 2012 .

7. Matthew Calarco, 'Between Life and Rights,' The Death of the Animal: A Dialogue, New York, Columbia University Press, 2009, pp135138, p138.

8. Calarco, Zoographies, op. cit., p13.

9. Vincent W. Lloyd, The Problem with Grace: Reconfiguring Political Theology, Stanford, Stanford University Press, 2011, p2.

10. Ibid., p2. 
11. Calarco, 'Toward an Agnostic Animal Ethics,' in Death of the Animal, op. cit., p78.

12. Gillian Rose, Mourning Becomes the Law: Philosophy and Representation, Cambridge,

Cambridge University Press, 1996, p37.

13. Giorgio Agamben's Homo Sacer: Sovereign Power and Bare Life, Daniel Heller-

Roazen (trans),

Stanford, Stanford University Press,

1998; Remnants of

Auschwitz: The Witness

and the Archive,

Daniel Heller-

Roazen (trans),

New York, Zone

Books, 1999; and

State of Exception,

Kevin Attell (trans),

Chicago, University

of Chicago Press,

2005.

14. The "broken

middle' is explored

throughout Rose's

work. See Hegel

London, Verso,

2009; Dialectic of

Nihilism: Post-

Structuralism and

Law, Oxford:

Blackwell, 1984; The

Broken Middle: Out

of Our Ancient Society

(Oxford: Blackwell,

1992). For Rose's

critique of Levinas

and Weil, see 'Angry

Angels: Simone

Weil and Emmanuel

Levinas,' in Judaism and Modernity:

Philosophical

Essays, Cambridge,

Blackwell, 1993.

15. Cora Diamond, 'Injustice and Animals', in Slow Cures and Bad Philosophies: Essays
Indeed, The Problem With Grace draws explicitly on the work of the philosopher/ sociologist/theologian Gillian Rose and her concept of the 'broken middle', to which I too will shortly refer. In light of Agamben and Levinas' respective legacies, I want to question the emphasis placed on the figures of exclusion and exception as symptomatic of supersessionist thinking. In Agamben, they appear in the figure of homo sacer (as well as the Muselmann) in his state of 'bare life,' while in Levinas it is the unseated self, dissolved in the scorching glory of the Other.

Levinas' exceptional gesture is revealed in the undoing of the self's intentionality and self-presence, the self 'held hostage' by radical alterity. Exclusion in Levinas is not, therefore, only exclusion pertaining to the Other, as we might initially intuit, but the exclusion of the self as wilful subject and sovereign. Levinasian exclusion is carried forth by the sweeping formlessness, indeed lawlessness, of the other person who is always already before or beyond me and whose transcendence infinitely exceeds totalization. The ethical encounter according to Levinas is precisely this traumatizing and disrupting of the imperial self by the Other's boundless destitution. Seen positively, in Calarco's succinct formulation, Levinasian ethics is 'an interruption of my egoism coming from the face of an Other that transforms my being in the direction of generosity'. ${ }^{11}$ Rose reads this transformation negatively as an expression of nihilism and a rejection of reason: 'to become ethical, this self is to be devastated, traumatised, unthroned, by the commandment to substitute the other for itself'. ${ }^{12}$ Agamben's exclusory gesture, in the form of the 'state of exception' and bare life explored in the series of homo sacer books, signals the biopolitical focus on bodily exposure - the body's devastation that cements sovereign power. $^{13}$

In a sense, then, ethics and biopolitics represent opposite discourses: the former emphasizes the absolute exteriority of the Other who is otherwise than being or beyond essence, while the latter signals a return to embodiment as the bedrock of sovereign life. Yet from the point of view of the idiom of exclusion, we can recognize in the swings between ethics and biopolitics a kind of impatience with what Rose called 'the broken middle', an impatience tantamount to a purism and Puritanism which for Rose border on the nihilistic. $^{14}$

An unqualified fascination with versions of extreme exclusion constitutes the bipolar turn in critical theory. The salvific urge underlying such radicalizations seems to me potentially to limit the ways we feel capable of speaking about the pressing issue Cora Diamond labelled plainly as 'injustice and animals', ${ }^{15}$ ways that are not reducible to the forsaken dispensable body or the Other's overwhelming vulnerability - 'overwhelming' in the double sense of verb (the Other's 'hyper-active' battering of the self) and adjective (the Other's 'hyper-passive' weakness that disarms the self). ${ }^{16}$ We would do better, I think, to return, compelled by the insights provided by Agamben and Levinas, to a 'civilized' discussion not only of exclusion and exception as 
the sole loci of oppression, but of exploitation and justice: a return, that is, to the elaborate, mundane realities and structures of power, oppression, and exploitation (of humans and other animals) and the agendas for combating them. Put differently, a preoccupation with radical Otherness threatens to lock us into a hypnotic vacillation between the two polar positions alluded to by Connolly: between the position of radical transcendence (ethics) and radical immanence (biopolitics). We may seek relief from violence in what Judith Butler calls 'a new bodily ontology' or else in a flight from subjectivity via the magnetism of the Other. ${ }^{17}$ That the opposition between radical transcendence and radical immanence is finally cosmetic is apparent from their common dependence on states of exception and the uncanny resemblance between the unknowable, well-nigh material opacity of the Levinasian Other and the bare, well-nigh abstract translucence of homo sacer.

The problem of violence, at the root of Levinas and Agamben's reflections on subjectivity, sociality, and the political, and at the centre, too, of animal ethics, cannot be fully addressed in reference to the two states of exception. For the issue of violence to come fully into view, one needs to acknowledge the potential of violence beyond all mechanisms of exclusion. That way lies a truly troubling proposition: that violence does not solely depend on mechanisms that distance and estrange, that frame lives in such a way as to render them ungrievable, but also and simultaneously on mechanisms that presuppose kinship and precariousness: violence is always also domestic violence. It is in this light that the potential for violence - and its alleviation - materializes most consequentially. In violence, processes of othering fluctuate, interchange, and intermingle with the recognition of precariousness and kinship, rethought as a complex and belligerent zone. For without the recognition of the Other's suffering and injurability, violence has neither meaning nor function and loses its somber, titillating drive.

To situate the problem of violence strictly in mechanisms of exclusion is to seek release from violence in the gestures of indefinite hospitality and welcome. For Rose, violence, for example the violence of Auschwitz, is thought through and countered in the persistence of both subjectivity and the municipality, not in the desire for their ultimate surpassing. To think municipally of Auschwitz means refusing to understand it as the demonic inversion of the 'first city' of Reason (Athens), as 'the end-product and telos of modern rationality'. ${ }^{18}$ The condemnation of reason as inherently murderous culminates in the fantasy of a 'second city' (New Jerusalem) with its promise of a 'new ethics of the unbounded community'. ${ }^{19}$ In this constellation of cities, Auschwitz becomes the 'fourth city,' after Athens and Jerusalem, disclosing a mediating third: Auschwitz 'arising out of, and as falling back into, the ambitions and the tensions, the utopianism and the violence, the reason and the muddle, which is the outcome of the struggle between the politics and the anti-politics of the city. This is the third city - the city in which we all live and with which we are too familiar'. ${ }^{20}$ The 'third city' - neither Athens nor a

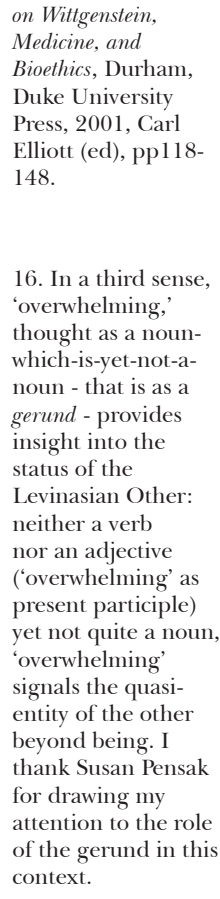

16. In a third sense 'overwhelming,' thought as a nounwhich-is-yet-not-anoun - that is as a gerund - provides insight into the status of the Levinasian Other: neither a verb nor an adjective ('overwhelming' as present participle) yet not quite a noun, 'overwhelming' signals the quasientity of the other beyond being. I thank Susan Pensak for drawing my attention to the role of the gerund in this context.

\section{Judith Butler,
Frames of War: When is Life Grievable?, London, Verso,} 2009, p2. 
21. Saul Bellow, $M r$. Sammler's Planet, London, Penguin, 1995 [1970], pp1314.

22. G.K. Chesterton, Orthodoxy, Massachusetts, Hendrickson Publishers, 2006 [1908], p11.

23. Ibid., pp10-11.
New Jerusalem - is where the difficult work of justice, ethics, and politics is undertaken.

There is, moreover, something faulty in the idea that now - in the aftermath we call modernity and postmodernity - the 'old' ontologies are defunct and we no longer know what it means, in Butler's words, 'to apprehend a life'. Here, the reflections of two reactionaries may offer some assistance. The eponymous Artur Sammler, in Saul Bellow's 1970 novel Mr. Sammler's Planet, provides a disgruntled rebuke of Hannah Arendt's idea of the 'banality of evil':

The idea of making the century's great crime look dull is not banal. Politically, psychologically, the Germans had an idea of genius. The banality was only camouflage. What better way to get the curse out of murder than to make it look ordinary, boring, or trite? ... But do you think the Nazis didn't know what murder was? Everybody (expect certain blue-stockings) knows what murder is. That is very old human knowledge. The best and purest human beings, from the beginnings of time, have understood that life is sacred. To defy that old understanding is not banality. There was a conspiracy against the sacredness of life. Banality is adopted disguise of a very powerful will to abolish conscience. Is such a project trivial? Only if human life is trivial. The woman professor's enemy is modern civilization itself. She is only using the Germans to attack the twentieth-century - to denounce it in terms invented by Germans. Making use of tragic history to promote foolish ideas of Weimar intellectuals. ${ }^{21}$

Bellow's borderline misanthropy and misogyny aside (Arendt is no 'bluestocking'), the insistence on the 'old human knowledge' of life's sacredness, what in a secular register is called 'precariousness', precisely asserts an 'old bodily ontology', which the crisis of European modernity, whose apotheosis is the Holocaust, allegedly threw into radical doubt. Bellow's character calls for the restoration of the one and only bodily ontology, which we must insist upon in the face of Auschwitz.

Similarly, G.K. Chesterton decries the repression of the 'fact of $\sin ^{22}$ in an example that returns us to the matter of animals:

If it be true (as it certainly is) that a man can feel exquisite happiness in skinning a cat, then the religious philosopher can only draw one of two deductions. He must either deny the existence of God, as all atheists do; or he must deny the present union between God and man, as all Christians do. The new theologians seem to think it a highly rationalistic solution to deny the cat. ${ }^{23}$

To 'deny the cat', to misapprehend its life, is for Chesterton objectionable from both the point of view of the thoroughly 'modern' atheist and the 'pre-modern' believer. In these accounts, the 'loss' of the cat - the loss of what Butler calls 
the intelligibility of life as a life - is akin to what Cary Wolfe, in his discussion of Stanley Cavell, describes as the post-Kantian 'loss of the world' and Rose, in Hegel Contra Sociology, analyzes under the 'neo-Kantian paradigm'. ${ }^{24}$ There is no cat, and therefore no crime nor the concomitant jouissance of criminality. For Bellow and Chesterton such scepticism is not only tragic but fake, and it dangerously undermines the prohibition against murder.

My understanding of Butler's work on precarity and precariousness is as an attempt to navigate between the two extremes: the insistence on the immediacy and availability of life as a life, and the 'loss of the world' that separates the apprehension or appearance of living from the ethical recognition of precariousness: 'to say that a life is precarious requires not only that a life be apprehended as a life, but also that precariousness be an aspect of what is apprehended in what is living..$^{25}$ In Butler's account precariousness is simultaneously normatively recognized and yet what escapes recognition. Precariousness is not simply finitude, the solitary (Heideggerian) being-towards-death. It is a condition that always already implies 'living socially, that is, the fact that one's life is always in some sense in the hands of the other'. ${ }^{26}$ Precariousness is therefore a grounding that is also a 'kind of "ungrounding", ${ }^{27}$ bodily exposure inscribed in the Levinasian substitutional structure of the-one-for-the-other.

Butler's own framing of animals' lives as ungrievable both validates her analysis and shows its weakness. 'Precarious life implies life as a conditioned process, and not as the internal feature of a monadic individual or any other anthropocentric conceit'. ${ }^{28}$ This, I argue, highlights some of the limitations of accounts that locate violence in the mechanisms of exclusion and othering and seek a remedy in a 'radical' politics of precariousness - a politics rooted in the immanence of bodily exposure and oriented towards the saving transcendence of alterity that 'calls into question the ontology of individualism'. ${ }^{29}$ But anthropocentrism and the self are not synonymous terms, and there is a space - it may well be the space of subjectivity as such - where I encounter my own negativity and inhumanity; the possibility that in its posited particularity [the subject] may be constantly exposed to the aporia not the self-identity - of its particularity with the singularity and universality of itself and others' ${ }^{30}$ More importantly in the present context, if we do need a 'new' bodily ontology that is first and foremost nonanthropocentric, this is an ontology which Butler's account, for all that is progressive about it, falls short of delivering.

\section{POSTHUMANIST ETHICS}

Who also hath made us able ministers of the new testament; not of the letter, but of the spirit: for the letter killeth, but the spirit giveth life. ${ }^{31}$

In a move that radicalizes Levinas (and Butler), Calarco states that if it is

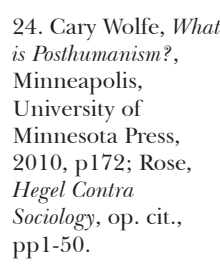

28. Ibid., p23.

29. Ibid., p33.

\author{
30. Rose, Mourning \\ Becomes the Law, op. \\ cit., p56.
}


32. Calarco, Death of the Animal, op. cit., p79.

33. See especially parts III \& IV of Radicalizing Levinas, New York, SUNY Press, 2010, Peter Atterton and Matthew Calarco (eds), Calarco's 'Faced by Animals' develops the argument for a 'rigorous ethical agnosticism' (xv) that necessarily includes animals.

34. On moral status see Chapter 2 in Paola Cavalieri's The Animal Question: Why Nonhuman Animals Deserve Human Rights, Oxford, Oxford University Press, 2001, pp2341, and Mary Anne Warren's Moral Status: Obligations to Persons and Other Living Things, Oxford, Oxford University Press, 1997, 2000 .

35. Calarco, Death of the Animal, op. cit., p79.

36. Ibid., p81.

37. Clare Palmer, Animal Ethics in Context, New York, Columbia University Press, 2010.

38. See for example Claire Colebrook's

'Queer Vitalism,' new formations 68 (April 2010): 77-92. Erica Fudge's 'Renaissance Animal Things' invokes 'Actor Network Theory' and 'thing theory' to explore the 'vital' relationships in early modern England between humans and indeed the case that we cannot know in advance where the face begins and ends ... we are obliged to proceed from the possibility that anything might take on a face. And we are further obliged to uphold this possibility permanently open'. ${ }^{32}$ Such ethical 'agnosticism' fulfils the promise of Levinasian ethics by, as it were, maintaining the alterity of alterity. ${ }^{33}$ 'Toward an Agnostic Animal Ethics' is a response to Paola Cavalieri's philosophical dialogue 'The Death of the Animal', in which Cavalieri advances a non-perfectionist, non-speciesist recognition of the 'moral status' of (some) nonhuman animals. As Calarco sees no objective, legitimate limit, cap, or criterion for excluding certain beings from access to moral consideration, he rejects the concept of 'moral status' as by definition exclusory and excluding. ${ }^{34}$ While ethical agnosticism is not immediately concerned with the range of existing things such as plants and objects, Calarco is aware of the risk of a universal moral consideration that presupposes no inside/outside:

While it might not be unreasonable to consider the possibility that animals who are subjects (which is where Cavalieri draws the line of moral consideration) could have a moral claim on us, are we also to believe that animals without any sort of subjectivity, as well as insects, dirt, hair, fingernails, ecosystems, and so on could also have a claim on us? ${ }^{35}$

'It is important to stress', Calarco replies, that 'universal consideration does not make the positive claim that all things or all life forms do count; nor does it supply any positive claim concerning how various beings or relational structures might count'. ${ }^{36}$

The creaturely approach I propose embraces the notion that everything counts. To be is to count, and in this respect ethical openness is synonymous with, cannot escape, the conviction that things matter, and matter morally. Where I agree with Calarco is that how things matter is, as Clare Palmer has shown, contextual, as well as dependent on the (ever-shifting) limits of our attention. ${ }^{37}$ Nevertheless, Calarco's account of agnostic animal ethics chimes rather strikingly with the present resurgence in vitalist and 'new materialist' theory engaged in a double 'awakening': the reawakening of 'inanimate' matter itself, the view of life as essentially expressive, and a reawakening of our own heretofore inanimate, 'dead' (dualistic, one-directional, instrumental) relationship to matter. ${ }^{38}$

Jane Bennett's exhilarating Vibrant Matter (reviewed in new formations by Graham Harman) presents 'vital materialism' as a form of acknowledgement of the reality (the vitality) of matter. Bennett is keen to tap the potential of this new 'political ecology of things', and although not explicitly interested in universal moral consideration, the framework of relations in Bennett's work is certainly, even literally, universal. ${ }^{39}$ Whereas Calarco invokes the 'outside' of transcendent alterity as the source of an open ethics of life, Bennett works through the 'inside' of immanence to assert similarly open-ended living 
multiplicities; Calarco's ethics is heteronomous, Bennett's is autonomous. Here again, we can detect the two currents of immanence and transcendence paralleling or mirroring one another.

But where are the complementary axial gestures of the movement inward and downward, the 'fall towards the heights,' in post-anthropocentric transcendental Levinasianism? Calarco realizes the importance of returning from love to law, the demands issued by the immanent and the concrete, the finite relations and practices that have to be considered under the auspices of universal moral consideration: indeed, the focus on animals in particular is itself a tacit acknowledgement of this. Still, Calarco's return to immanence remains largely 'strategic'; it is the alterity of animals that is key. ${ }^{40}$ Conversely, Bennett's admirable, often moving readings remain purely immanent. One wonders, therefore, whence the ethical command to relate differently - to relate justly - to the many things of the world, to welcome them in their vitality and alterity, emanates. Why should the recognition of the vitality of matter itself enhance ecological multispecies responsibility? Kathryn Yusoff's analysis of the 2011 UK government's White Paper The Natural Choice: Securing the Value of Nature suggests that not only is a 'vibrant' conception of nature itself insufficient, but actually exacerbates the exploitation of nature, seen now not only as raw material or 'standing reserve' but as an active deliverer of 'ecosystem services'. ${ }^{41}$

If neither the appeal to radical immanence nor the appeal to radical transcendence independently yields the ethical consideration we seek, a different constellation is required. To the recognition of the 'immanence of the world', I want to add an engagement with ideas deriving from the 'transcendence over the world', and vice versa. The manoeuvre insists that pure immanence or pure transcendence alone does not engender viable ethical and political possibilities since each replicates rather than problematizes the metaphysical notion of an absolute yet arbitrary foundation.

In a recent TLS review of Conor Cunningham's Darwin's Pious Idea, Rowan Williams argues for precisely such a rapport between the theological and the materialist reference points. Echoing Bennett's recognition of matter's agentic capacities - what she calls 'thing power' - Williams endows matter with 'the possibility of mind' ${ }^{.2}$ Williams' conception of matter can be read, in Bennett's register, immanently; indeed one can think of Williams' account as representing the parallel attributes of Spinoza's one substance ('God or Nature'): extension (matter) and thought (consciousness). ${ }^{43}$ 'Matter itself is pregnant with meanings', Williams continues, 'in the sense that the complexification of matter over the ages ends up in the phenomenon of consciousness'. ${ }^{44}$ Discussing the implications of the rise of genetics, Williams suggests that 'something seriously analogous to intelligence has to be presupposed in matter for the entire system of transmitted patterns and "instructions" to be possible'. ${ }^{45}$ Yet this mapping on of mind to matter and matter to mind, the idea promoted by some physicists that it is more true to

animal commodities.

39. Jane Bennett, Vibrant Matter: $A$ Political Ecology of Things, Durham, Duke University Press, 2010

40. Calarco, Death of the Animal, op. cit., p82.

41. Kathryn Yusoff, 'The Valuation of Nature: The Natural Choice White Paper,' Radical Philosophy 170 (November/ December 2011), http://www. radicalphilosophy. com/commentary/ the-valuation-ofnature (accessed 17 January, 2012).

42. Rowan Williams, 'Such a Thing', TLS, 22 April, 2011 , pp8-9.

43. In the Ethics Spinoza states that 'thinking substance an extended substance are one and the same substance, comprehended now under this attribute, now under that. So, too, a mode of Extension and the idea of that mode are one and the same thing, expressed in two ways' (Pr. 5, II). Baruch Spinoza, Ethics: Treatise on the Emendation of the Intellect and Selected Letters, trans. Samue Shirley, Cambridge, Hackett Publishing, 1992.

44. Williams, 'Such Thing', op. cit., p8.

45. Ibid., p8. 
46. Ibid.

47. Ibid., p8 (my emphasis).

48. Stanley

Hauerwas, The Peaceable Kingdom: A Primer in Christian Ethics, London, SCM Press, 2003, p16.

49. Gillian Rose's Love's Work: A Reckoning with Life was first published in 1995. My references are to the new edition, New York: New York Review Books, 2011.

50. Weil, Gravity and Grace, op. cit., p108. say matter is a property of consciousness than the other way around - echoing the ancient philosophical dictum that the body is "in" the soul rather than the soul in the body', ${ }^{46}$ undergoes a specifically Christian turn in Williams' subsequent point that

the evolutionary model he [Cunningham] has supported, especially in its anti-dualism, is wholly congruent with the mainstream of Christian metaphysics and theology ... We can easily make the mistake of thinking that materiality is itself the problem; but the whole structure of Greek patristic and medieval Christian thinking should direct us firmly away from this, and recall us to the conviction of the sacredness of matter which stands at the heart of classical Christian doctrine. ${ }^{47}$

This translation from immanent materiality to the transcendence of the sacred and from materiality and the sacred to the doctrinal are at the heart of a creaturely ethics. Ethics is not sanctioned from above or below. As the theologian Stanley Hauerwas has argued, 'our moral life is the process in which our convictions form our character to be truthful'. ${ }^{48}$ Creaturely ethics does not justify itself at the level of materiality and finitude because these alone do not constitute an obligation or a command; nor does creatureliness simply ascribe the sanctity of matter to a source outside the world. It is precisely the lived conjunction between here and elsewhere that enables a critique of liberal moral theory and the ethics of the Other alike.

At the end of the essay I provide my own 'doctrinal' exchange between love and law in the everyday practice of veganism, which I regard as an expression of a creaturely sensibility that exceeds the discrete notions of moral status and animal rights and embraces a more comprehensive attitude which is both legalistic (in that it prohibits the consumption of animal products) and amorous (in that it affirms a relation of love towards fellow creatures) veganism as a form of 'love's work'. ${ }^{49}$

\section{CREATURELY ETHICS: NECESSITY AND ATTENTION}

The apparent circularity of Simone Weil's statement that 'the vulnerability of precious things is beautiful because vulnerability is a mark of existence' reveals the conflation in her life and thought between the immanent and the transcendent. ${ }^{50}$ Seemingly tautological, the statement affirms that existing things must be loved, and loved because they exist, because they are vulnerable. Vulnerability, beauty, and existence are terms that repeat one another in three registers: the ontological, aesthetic, and ethical. But the tautology is only superficial. The intention is not only to represent necessity in words through the circular structure, but for the sentence to institute, to become necessity. The idea that necessity should be loved as necessity is central to Weil and reminiscent of both Nietzsche and Spinoza, for whom understanding the 
necessary connections that refute contingency is the highest good (Spinoza calls this intellectual love, or amor dei intellectualis). For Weil,

[t] he beautiful in nature is a union of the sensible impression and the sense of necessity. Things must be like that (in the first place), and, precisely, they are like that. ${ }^{51}$

51. Ibid., p148.

Necessity, the 'mechanism of the world' represented by logic (and revealed to the mind in pure mathematics) is equivalent to transcendence, or grace. Gravity and grace are brought together when one sees through the mystifications of ideology and psychology and into the conditions of reality. Perceived as necessity, reality becomes beautiful because we no longer desire to 'redeem' it by imagining it as something that obeys our fantasies about how things ought to be. Political and ethical transformation according to Weil occurs within, not beyond, the idea of necessity: 'To act not for an object but from necessity'. ${ }^{52}$ Weil is a strict realist: she understands that meaningful change comes from an adequate appreciation of necessity.

As an ethics of life, creatureliness does not simply denote embodiment but a particular comportment towards the finitude, abundance, and vulnerability of materiality recognized as necessity. To say that the creaturely is indifferent to human and nonhuman life is to sidestep deconstructions of the human/ nonhuman boundary as largely extraneous. While conceptually attractive, efforts to undo human identity run the (Levinasian) risk of a flirtation with Otherness at the expense of examining the concrete relations of power that underwrite human domination of animals. If meat consumption, factory farming, land encroachment, species extinction, and vivisection are anything to go by, the exploitation of nonhumans continues unabated and has even intensified in the posthuman age (when breakthroughs in biotechnology have unsettled the classic understanding of the human). We could argue that there is simply too much "bad" posthumanism' around..$^{53}$ Or it may be that it is not enough to pursue the 'end' of the human subject (as either what comes after or as that which never was) without committing to and detailing a revised order of relations, which turns 'us,' whatever we happen to be, towards animals in a decisively different way.

In keeping with ethical agnosticism, creaturely ethics does not seek out the qualities or capacities that warrant inclusion in the moral community but rather suggests that all existents by virtue of their perishable material being are morally significant. Creatureliness is thus critical of the idea of moral status, linked to the dominant 'capabilities model' of animal rights. The capabilities model, which infuses the utilitarianism of Peter Singer and the rights models of Tom Regan and Martha Nussbaum, allocates rights in accordance with abilities that nonhuman animals are deemed to possess, be they, roughly, cognitive (Cavalieri), sensate (Jeremy Bentham, Singer), or existential (Regan, Nussbaum). 
54. Weil, Gravity and Grace, op. cit., p116.

55. Ibid., pp116117.

56. Ibid., p118.

57. Ibid.

58. Lloyd, The Problem with Grace, op. cit., p124.

59. Weil, Gravity and Grace, op. cit., p119.

60. Lloyd, The Problem with Grace, op. cit., p124.
By contrast, a creaturely ethics does not rest on capacities that nonhuman animals may (or may not) possess, on the basis of which they would be 'granted' or 'owed' particular rights. Instead of extending rights to deserving animals, based on our sense of what it means to be a moral subject or patient, creatureliness contracts humanity to recuperate its animality. In rooting ethical thought first and foremost in materiality and not in the rights of 'qualified' individuals, the distinctions between humans and animals, as far as ethical consideration is concerned, are erased. Not only does creatureliness apply across the range of living beings and so go beyond Agamben's bare and Butler's precarious life, it draws on the predicament of animals as exemplary of precarity as such.

While agnostic, creatureliness is not an ethics of the indefinite Other. From the intimations of alterity, creatureliness rebounds to the normative requirements of daily life. It does so by employing the mode Weil calls 'attention'. As in Levinas, attention suspends the egotistical, muscular will. Whereas 'I can will to put my hand on the table', the will does not partake in matters of 'inner purity, inspiration or truth of thought'. 54 'What could be more stupid than to tighten up our muscles and set our jaws about virtue, or poetry, or the solution of a problem. Attention is something quite different' ${ }^{55}$ Attention is a relaxing of the will that opens to the outside by drawing back from the object. In solving a mathematical problem, for instance, the mind, momentarily emptied of the imaginings of self (my fear that I am no good at maths, my pride at being naturally gifted, my desire for a good mark, etc.) makes a space for truth (necessity) to fill. Thus, to do well, and to do good, "[a]ttention alone - that attention which is so full that the "I" disappears - is required of me'. ${ }^{56}$ Attention means being lost in the undertaking and separated - detached - from my personal or societal 'investment' in the particular task.

In seeking justice for animals, rights and the capabilities model represent a wilful tackling of the issue. These approaches are not sufficiently detached from the problem they face and so produce forced explanations that 'defeat their own object': ${ }^{57}$ animals as 'subjects-of-a-life' (Regan), utilitarian calculations of the sum total of pleasure and pain (Singer), the predicates of 'moral status' (Cavalieri) distract from attention to animals that sees them and us first in our necessity as 'modes' of nature (to use Spinoza's term). Only once necessity has been glimpsed through attention can particular actions be tested out in real life. As Lloyd explains, for Weil '[a]ttention is the only genuine source of obligation' ${ }^{58}$ because 'attention turned with love towards God (or in a lesser degree, towards anything which is truly beautiful) makes certain things impossible for us' ${ }^{59}$

Weil's religious rhetoric can seem alien, even off-putting. But God here functions as 'that which makes attention possible', ${ }^{60}$ the mode of approaching a question or a task that detaches itself from the contaminating presuppositions of social convention, passions like fear and pride, or philosophical (and, for 
that matter, religious) dogma. So Weil is not, as might first appear, a bipolar (supersessionist) thinker opposing 'worldly' to 'divine obligation' ${ }^{61}$ Turning towards animals via the mode of attention means acknowledging their reality, not subjecting them to some otherworldly principle of divine grace. When attention sees the beauty of the 'vulnerability of precious things' as their 'mark of existence,' there is an interdiction against violence:

The beautiful is a carnal attraction which keeps us at a distance and implies a renunciation. This includes the renunciation of that which is most deep-seated, the imagination. We want to eat all the other objects of desire. The beautiful is that which we desire without wishing to eat it. We desire that it should be. ${ }^{62}$

The omnivorous orality of the human psyche is fuelled by an imaginary attachment to objects. Attention (not analysis) can help counter the imagination, which pleases by mystifying and perverting our relations to others. Beauty is, once more, not elevated but earthly: we see the beauty of objects when we peel off their imaginary coating through the practice of attention.

Weil's thought is in the shape of the cross. The intersecting of gravity and grace, verticality and horizontality, love and law, is apparent in the aphoristic, compact, and chiastic form of her prose. But we are not encouraged to aspire to the heights, to defy gravity and levitate by the power of grace. As Lloyd poignantly puts it: "while gravity goes down, grace does not go up. Grace goes down "without weight". To understand this is to understand Weil's thought'. ${ }^{63}$ This is the meaning of descending upwards, or love's work.

63. Lloyd, The Problem with Grace, op. cit., p141.

\section{LOVE'S WORK}

One must either not eat any meat, not kill any animals; or look upon animals as machines after the style of Descartes; or surround their death with certain religious images. Otherwise, what is more calculated to take away all notion of morality in children?

Simone Weil ${ }^{64}$

64. Simone Weil, The Notebooks of Simone Weil, vol. 2

I will stay in the fray, in the revel of ideas and risk; learning, failing, wooing, grieving, trusting, working, reposing - in this sin of language and lips.

\section{Gillian Rose ${ }^{65}$}

Veganism is a form of 'love's work'. The idea that veganism has meaning Arthur Wills (trans), London, Routledge, 1976, p.537.

65. Rose, Love's Work, op. cit., p144. both as a philosophical argument and as mode of social and, for that matter, liturgical practice is often overlooked in debates in animal ethics that 
66. Stanley

Hauerwas and John Berkman, 'The Chief End of all Flesh', Theology Today 49, no. 2 (July 1992): 196-208. I thank Jasmin Singer, Mariann Sullivan, and Nick Laccetti of Our Hen House, http://www. ourhenhouse.com/, for introducing me to Hauerwas' work.

67. Gillian Rose, 'Interview with Gillian Rose: Edited and Introduced by Vincent Lloyd', Theory, Culture $\&$ Society 25

(December 2008): 201-218, http:// tcs.sagepub.com/ content/25/7-8/201. full.pdf (accessed 26 July 2011).

68. Donna Haraway, When Species Meet,

Minneapolis,

University of

Minnesota Press, 2008.

69. Hauerwas and Berkman, 'The Chief End of all Flesh', op. cit., p197.

70. Ibid., p197 (my emphasis). distinguish 'theory' from 'practice'. I want to offer a different description of veganism that re-inscribes it in the Continental tradition within which I converse. This is not only to pre-empt the usual question that follows the elucidation of a crisis: So what, then, do you propose we do? but to re-contextualize veganism as a way of living, an act that, far from assuming the position of moral superiority (with its tacit admonition to non-vegans) or indicating a degree of remove from daily life, entails in its very incompleteness and imperfections, a conscious participation in the world, participation with a difference - the descending upwards of Weil's 'fall towards the heights'.

Veganism does not draw back from violence in the conceit that violence will cease. The pacifist is not a vegan insofar as pacifism refuses to accept the reality of violence as a limit. Hauerwas and Berkman's comments on the connections between (Christian) pacifism and vegetarianism make a similar point: 'we believe that Christians are not called to be nonviolent because nonviolence is a strategy to free the world from war, but because as Christians we cannot conceive of living other than nonviolently in a world of war' ${ }^{66}$ Veganism is a constant reminder of the omnivorous orality that propels us towards beings and things - things we approach by devouring. As a particular way of 'eating' (in the sense of coming into contact, of consuming and becoming, but also commingling with and responding to the symbolic and biological agency of encountered, ingested matter) veganism is also an affirmation of hunger as desire and love of the world: 'Eros ranges from sexual desire to intellectual curiosity. It's just a hunger' ${ }^{67}$

My understanding of veganism as an acknowledging of creaturely love is not dissimilar from the approach developed by Donna Haraway in When Species Meet. For Haraway, 'becoming-with' entails realizing that we are always living and transforming with the assemblages of nonhuman critters that surround and inhabit us. Clearly, eating animals is a key issue in such interspecies entanglements. A detailed response to Haraway is impossible here, but the contours of our disagreement are significant. I cannot detach the idea of love that underpins Haraway's accounts of interspecies 'worlding' from an abstention from consuming animal flesh. While I agree that hunters, for example, may relate to their prey in complex ways, I have difficulty conceiving this as a relation of love. ${ }^{68}$ How are the practices of hunting and love compatible? We need to discuss what exactly we mean when we say we 'love' animals, but I concur with Hauerwas that 'our practices with regard to other animals shape our beliefs about them' ${ }^{69}$ If 'our practices, more than our arguments, reveal and shape what is truly important to us', then 'vegetarianism may well be a prerequisite', not the end, of animal ethics. ${ }^{70}$

Legal scholar Gary Francione is a passionate advocate of veganism as the 'moral baseline' of the animal rights movement. The abolitionist theory developed by Francione is rarely discussed in works of a Continental bent. This is one reason for including abolitionism here, in the context of a creaturely postscript on veganism. The second is that Francione's abolitionism rests on 
the claim that 'animal rights theory is the only way to alter the status of animals as property, or "things", and thereby eliminate the person/thing dualism that is the foundation of all institutionalized exploitation'. ${ }^{71}$ Francione believes that rights theory is by definition abolitionist, that it requires ending, not regulating the use of animals for human purposes. He distinguishes between the 'use' and 'treatment' of animals, and suggests that animal rights, in contrast to animal welfare, tackles the core issue of animal use. ${ }^{72}$

Francione's abolitionist vegan advocacy is consistent with the approach to animal ethics I have been developing. Yet Francione's thinking falls firmly on one side of the division between love and law. His animal rights theory is a clear example of the understanding of animal exploitation, and the solution to it, in purely legal terms:

We can use animals for food, in experiments, for clothing or entertainment only because animals are things; they have no interests that cannot be 'sacrificed' if it is thought (correctly or mistakenly) to be in the interests of humans. This is precisely what it means to be property. ${ }^{73}$

If earlier I showed ethics and biopolitics as highlighting the exception to law in the love/law divide, here the logic of exclusion is employed in the opposite direction to explain the prevalence of violence against animals. It is as if the presence of violence were the result of a legal error. Animals are not the Other that sustains (human) law; their faulty status within the law deprives them of the rights they would otherwise hold. Once the law is amended, violence will disappear. Again, violence is relegated to an outside, this time outside the realm of legalistic rational thought, and it is the task of the theorist, the activist, and the educator to restore rationality to end what is essentially the illogical perpetration of violence. In this respect, abolitionism and welfarism, despite their difference in relation to the question of treatment and use, both derive the meaning of oppression from a single, legal-rational, source: they disagree on the implications of 'property' and 'person' as legal categories that apply to animals. Welfare reform does not dispute the property status of animals, while abolitionism demands that animals cease to be property altogether.

Whereas welfarism is rightly unmasked by Francione as a humanist discourse that ranks human life essentially higher than animal life and so is prepared to exploit animals within the boundaries of 'humane' treatment, in abolitionism, too, we can identify a latent essentialism, a recognition of the sanctity or creatureliness of animal life that is pre- or supra-legal. The 'absolutism' that Francione's 'controversial' (his term) animal rights theory is sometimes accused of attests to this. But the moral force of abolitionist theory does not lie in either its alleged 'extremism' or its lucid legalisms. It lies, for me, in the combination between a legal proscription (to end the property status of animals) and the recognition of the precariousness of animal life that the notion of 'personhood', albeit imperfectly, implies. Francione

71. Gary L. Francione, Animals as Persons: Essays on the Abolition of Animal Exploitation, New York, Columbia University Press, 2008, p187.

72. Gary L. Francione and Robert Garner, The Animal Rights Debate: Abolition or Regulation?, New York, Columbia University Press, 2010.

73. Francione, Animals as Persons, op. cit., p187. 
74. Rose, Hegel Contra Sociology, op. cit., p218.

75. John M

Coetzee, 'Notes on Issues Raised by Matthew Calarco', in Death of the Animal, op. cit., p89. is in agreement with the more radical Continental thinkers that there can be no pre-conditions for moral consideration. Sentience alone is sufficient. I have shown how a range of approaches, including my own, go further than sentience, but abolitionism strikes me as the closest, most attractive articulation that Continental animal ethics points to without legislating.

Abolitionism is not, as it is sometimes portrayed, an 'all or nothing' utopian principle. Its insistence on veganism (rather than vegetarianism) and on the end (rather than the regulation) of animal use does not deny actuality. In Hegel Contra Sociology Rose explains the significance of 'thinking the absolute':

Thinking the absolute means recognizing actuality as determinants of our acting by recognizing it in our acts. Thus recognizing our transformative or productive activity has special claim as a mode of acknowledging actuality which transcends the dichotomies between theoretical and practical reason, between positing and posited. Transformative activity acknowledges actuality in the act and does not oppose act to non-act. ${ }^{74}$

Abolitionism remains a theory of the 'broken middle' that dares think the absolute. To claim that abolitionist thinking sets us up for failure because the absolute is, naturally, actually, impossible, is to misunderstand the nature and value of failing the absolute. For as Rose and as Weil each point out, reality (Weil) or actuality (Rose) can only be grasped in the act of its limited transforming once the absolute that transcends all limits and oppositions has been glimpsed.

Once its legalism has been confronted, deepened, and supplanted by the broader concerns about violence, alterity, precariousness, and justice that have animated the present discussion of creatureliness, abolitionism takes on the complexity and ambivalence - the limits placed by actuality - that it otherwise lacks. The abolitionist struggle becomes not strictly the matter of logical persuasion based on faith in the foundational authority of law but also a matter of law's Other - what J.M. Coetzee described as an ethical 'conversion experience'. ${ }^{75}$

Perhaps more than any other writer on the ethical question of animals, Coetzee explores the tensions between conversion (grace) and persuasion (reason). Is that not the meaning of Coetzee's title, Disgrace? And is not Elizabeth Costello similarly suspended between love and law and between mourning and melancholy, trying, and failing, to chart her way between the two poles? In 'The Comedy of Hegel,' Rose defends the dignity and decency of law in the face of the ethical touting of Otherness, and defines the brokenness through which life as mournful but necessary toil carries on:

if all human law is sheer violence, if there is no positive or symbolic law to be acknowledged - the law that decrees the absence of the other, the necessity of relinquishing the dead one, returning from devastating inner 
grief to the law of the everyday and of relationships, old and new, with those who live - then there can be no work, no exploring of the legacy of ambivalence, working through the contradictory emotions aroused by bereavement. ${ }^{76}$

76. Rose, Mourning Becomes the Law, op. cit., p70.

Creatureliness - freely attending to our own unfreedom, our rootedness in materiality and necessity - is the 'fall towards the heights'. The paradox of descending upwards entails being suspended between endless (rigid) love and rigid (endless) law. In Rose's beautiful words, inspired by Weil, which insist on the continuity between the corporeal, ethical, and political:

The pathos of gravity - of weight, ground, earth, city - channelled to grace - the response to ethical commandment - means that spiritual and religious life, supernatural, is not radically divorced from nature, being, logic and politics. ${ }^{77}$

Like Weil, Rose has little to say about animals. ${ }^{78}$ But the case of animals offers a particular challenge to the holding together of love and law, ethics and politics. Creatureliness pursues both sides of the division between the immanent and the transcendent, the lawlessness of love that shows up the limits of the contractarian framework, and the possibility of a different normative order. The creaturely is not a catchall term but rather allows us to consider the human and the animal in a state of suspension between exclusion and kinship without projecting innocence on either side. Rose said she was 'too Jewish to be Christian, and too Christian to be Jewish'. My sense of the creaturely repeats the chiasmus - in place of Derrida's 'the animal that therefore I am', this more follows: a creature too human to be animal and

77. Gillian Rose, Paradiso, London, Menard Press, 1999 p63.

78. But in Paradiso Rose writes of St Bernard who killed a blackbird that disrupted his preaching: 'How could St Bernard ... how can we know, whether it is not the blackbird who, with special sweetness, sings the Word of God?' (17). too animal to be human. 